\title{
Annual carbon gas budget for a subarctic peatland, Northern Sweden
}

\author{
K. Bäckstrand ${ }^{1}$, P. M. Crill ${ }^{1}$, M. Jackowicz-Korczyñski ${ }^{2}$, M. Mastepanov ${ }^{2}$, T. R. Christensen ${ }^{2}$, and D. Bastviken ${ }^{1}$ \\ ${ }^{1}$ Department of Geology and Geochemistry, Stockholm University, 10691 Stockholm, Sweden \\ ${ }^{2}$ GeoBiosphere Science Centre, Physical Geography and Ecosystem Analysis, Lund University, Sölvegatan 12, \\ 22362 Lund, Sweden
}

Received: 22 May 2009 - Published in Biogeosciences Discuss.: 15 June 2009

Revised: 22 November 2009 - Accepted: 11 December 2009 - Published: 11 January 2010

\begin{abstract}
Temperatures in the Arctic regions are rising, thawing permafrost and exposing previously stable soil organic carbon (OC) to decomposition. This can result in northern latitude soils, which have accumulated large amounts of $\mathrm{OC}$ potentially shifting from atmospheric $\mathrm{C}$ sinks to $\mathrm{C}$ sources with positive feedback on climate warming. In this paper, we estimate the annual net $\mathrm{C}$ gas balance (NCB) of the subarctic mire Stordalen, based on automatic chamber measurements of $\mathrm{CO}_{2}$ and total hydrocarbon (THC; $\mathrm{CH}_{4}$ and NMVOCs) exchange. We studied the dominant vegetation communities with different moisture and permafrost characteristics; a dry Palsa underlain by permafrost, an intermediate thaw site with Sphagnum spp. and a wet site with Eriophorum spp. where the soil thaws completely. Whole year accumulated fluxes of $\mathrm{CO}_{2}$ were estimated to 29.7, -35.3 and $-34.9 \mathrm{gC} \mathrm{m}^{-2}$ respectively for the Palsa, Sphagnum and Eriophorum sites (positive flux indicates an addition of $\mathrm{C}$ to the atmospheric pool). The corresponding annual THC emissions were $0.5,6.2$ and $31.8 \mathrm{gC} \mathrm{m}^{-2}$ for the same sites. Therefore, the NCB for each of the sites was 30.2, -29.1 and $-3.1 \mathrm{gC} \mathrm{m}^{-2}$ respectively for the Palsa, Sphagnum and Eriophorum site. On average, the whole mire was a $\mathrm{CO}_{2}$ sink of $2.6 \mathrm{gC} \mathrm{m}^{-2}$ and a THC source of $6.4 \mathrm{gC} \mathrm{m}^{-2}$ over a year. Consequently, the mire was a net source of $\mathrm{C}$ to the atmosphere by $3.9 \mathrm{gC} \mathrm{m}^{-2}$ (based on area weighted estimates for each of the three plant communities). Early and late snow season efflux of $\mathrm{CO}_{2}$ and THC emphasize the importance of winter measurements for complete annual $\mathrm{C}$ budgets. Decadal vegetation changes at Stordalen indicate that both the productivity and the THC emissions increased between 1970 and 2000. Considering the $\mathrm{GWP}_{100}$ of $\mathrm{CH}_{4}$, the
\end{abstract}

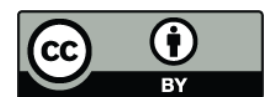

Correspondence to: K. Bäckstrand (kristina.backstrand@gmail.com) net radiative forcing on climate increased $21 \%$ over the same time. In conclusion, reduced $\mathrm{C}$ compounds in these environments have high importance for both the annual $\mathrm{C}$ balance and climate.

\section{Introduction}

Northern latitude soils store a large amount of organic carbon (C) due to a climate that causes low decomposition rates relative to production rates. The amount of organic $\mathrm{C}$ that is stored in northern latitude permafrost soils has been estimated to be as high as 1400 to $1850 \mathrm{Gt}$ (McGuire et al., 2008), which is at least double the current atmospheric $C$ pool ( $\sim 760 \mathrm{GtC}$; IPCC, 2001). Northern peatlands specifically are considered to account for 450 to $700 \mathrm{Gt}$ (Gorham, 1991; Zimov et al., 2006; McGuire et al., 2008) of this amount, while the rest has been proposed to be stored in other soils than peatlands and deep alluvial sediments ( $\mathrm{Zi}$ mov et al., 2006; McGuire et al., 2008). Concern has been raised whether these ecosystems will continue to be sinks of atmospheric $\mathrm{C}$ or if they will, or have already become $\mathrm{C}$ sources to the atmosphere. Temperatures in the Arctic regions have risen, causing thawing permafrost and exposure of previously stable soil organic $\mathrm{C}$ for decomposition processes. A potential shift from $\mathrm{C}$ sink to atmospheric $\mathrm{C}$ source would in turn increase the atmospheric burden of greenhouse gases and provide a positive feedback on climate warming.

However, the atmosphere and biosphere $\mathrm{C}$ exchange data in the northern latitudes are few considering the large area that they aim to represent, and the uncertainty about the current $\mathrm{C}$ balance of northern peatlands is large. Some limitations behind the scarce data availability arise from logistical limitations in the Arctic. Long-term (multi-year to decadal) data sets that are needed to gain knowledge about temporal

Published by Copernicus Publications on behalf of the European Geosciences Union. 
variability are also sparse and the spatial variation of soil properties, vegetation types and ecosystem structure is large which makes it difficult to scale up from plot scale to landscape scale level.

The $\mathrm{C}$ gas exchanges most frequently studied in the context of $\mathrm{C}$ budgets in northern peatlands are those of carbon dioxide $\left(\mathrm{CO}_{2}\right)$ and methane $\left(\mathrm{CH}_{4}\right)$. These studies have focused on the biologically active season and when conducted they are in most cases based on low temporal resolution data, i.e. days to weeks between sampling (Crill et al., 1992; Klinger et al., 1994; Oechel et al., 1995, 2000a; Heikkinen et al., 2002b; Heyer et al., 2002; Turetsky et al., 2002; Treat et al., 2007). While $\mathrm{CO}_{2}$ exchange is controlled by the balance of plant photosynthesis, and heterotrophic and autotrophic respiration processes, the $\mathrm{CH}_{4}$ surface exchange is determined by its production and consumption rates and transport processes in the soil profile (Joabsson et al., 1999). Very few studies have presented year around data for annual $\mathrm{C}$ budgets including both the $\mathrm{CO}_{2}$ and $\mathrm{CH}_{4}$ exchange from subarctic/Arctic environments. Many studies do not have any winter measurements, and annual $\mathrm{C}$ balance budgets of $\mathrm{CO}_{2}$ and $\mathrm{CH}_{4}$ exchange commonly include some assumed/modeled winter data to estimate an annual budget (e.g. Alm et al., 1997; Oechel et al., 2000b; Heikkinen, 2003; Nykänen et al., 2003; Corradi et al., 2005). Annual C balance budgets based solely on either $\mathrm{CO}_{2}$ (e.g. Aurela et al., 2002; Lund et al., 2007; Sagerfors et al., 2008) or $\mathrm{CH}_{4}$ (Rinne et al., 2007; Jackowicz-Korczyñski et al., 2009) are somewhat more common. Modeling studies of the annual $\mathrm{CO}_{2}$ and $\mathrm{CH}_{4}$ exchange of these ecosystems exist (e.g. Frolking et al., 2002; Grant et al., 2003; Sitch et al., 2007) but the frequency of original field observations is highly insufficient, i.e. the validation of these models suffers from lack of data. As noted by recent studies, there is also a need for including non-methane volatile organic compound flux (NMVOCs) when studying the C budget of subarctic ecosystems (Tiiva et al., 2007; Bäckstrand et al., 2008a; Ekberg et al., 2008; Tiiva et al., 2008), which has not been done previously on a more continuous basis.

In this paper, we present an estimate of the annual net carbon gas balance (NCB) of a subarctic mire, based on semi continuous measurements of both $\mathrm{CO}_{2}$ and total hydrocarbon flux (THC including $\mathrm{CH}_{4}$ and NMVOCs) measurements. We are using data from both snow and snow free seasons, the latter herein referred to as the green season. As in many of the other studies of annual balances, our data set still excludes measurements of mid-winter months and therefore we have come up with assumed snow season fluxes during this period to gap fill for the annual budget estimation. The period that has been gap filled is from early December to late March, but worth noticing is that even if 3 months of gap filling seems like a long period, the actual measurements during snow season has been conducted over a period of nearly 2 months before, and 1 months after the gap fill. Because of the high temporal frequency of the method adopted, the number of fluxes from this period is also high.
This study does not include the dissolved organic and inorganic C (DOC and DIC) and particulate organic C (POC) components of the Stordalen mire $\mathrm{C}$ budget. However, these components are of course necessary to do a full $\mathrm{C}$ budget and estimates of their exchange rates are presently under investigation by other research groups working at the mire.

The Stordalen mire, where the study has been conducted, is characterized by discontinuous permafrost which creates an environment with distinct differences in moisture and permafrost regimes as well as trophic status (Rosswall et al., 1975), which in turn drives a diverse vegetation distribution (Malmer et al., 2005). We have measured the $\mathrm{C}$ gas exchange at three localities that reflect the range of plant species distributions typical for three levels of moisture, nutrient and permafrost status found at the mire. The annual net $\mathrm{C}$ gas budget presented is based on six years of data (2002-2007), of which snow season data were collected during shorter periods in 2002, 2004, 2005 and 2007 while green season data were collected during longer periods in all years (2002-2007) using an automatic chamber (AC) system for $\mathrm{C}$ gas flux measurements at time levels ranging from hours to years. Some of the data included in this paper have previously been published by Bäckstrand et al. (2008a; 2008b), but in those cases focus was on determining NMVOC contribution to THC as well as spatial and temporal controls on THC exchange during the growing seasons, whereas this paper combines $\mathrm{CO}_{2}$ and THC exchange from both snow seasons and summer periods and estimates an annual $\mathrm{C}$ gas balance.

The Stordalen mire has been of environmental research interest for several decades. There are data available on plant community, permafrost distribution and $\mathrm{C}$ flux dynamics since the 1970s which have been compared to the state of the mire in the year of 2000 (Christensen et al., 2004; Malmer et al., 2005; Johansson et al., 2006). In these studies, focus was on the shorter green season $\mathrm{C}$ exchange, and $\mathrm{CO}_{2}$ data arrived to a lesser extent from continuously sampled data and $\mathrm{CH}_{4}$ fluxes were manually sampled with low temporal resolution. This report is a continuation of the previous ones by expanding with another 3 years of high temporal resolution $\mathrm{CO}_{2}$ fluxes as well as 6 years of high temporal resolution THC fluxes. In addition, an annual estimate can now be achieved by including data from the early and late snow season not previously published. It is important to take into consideration changes in permafrost distribution, and the associated spatial shifts in plant communities, when estimating how the $\mathrm{C}$ balance of the mire has changed over the decades, and how it may change in the future 


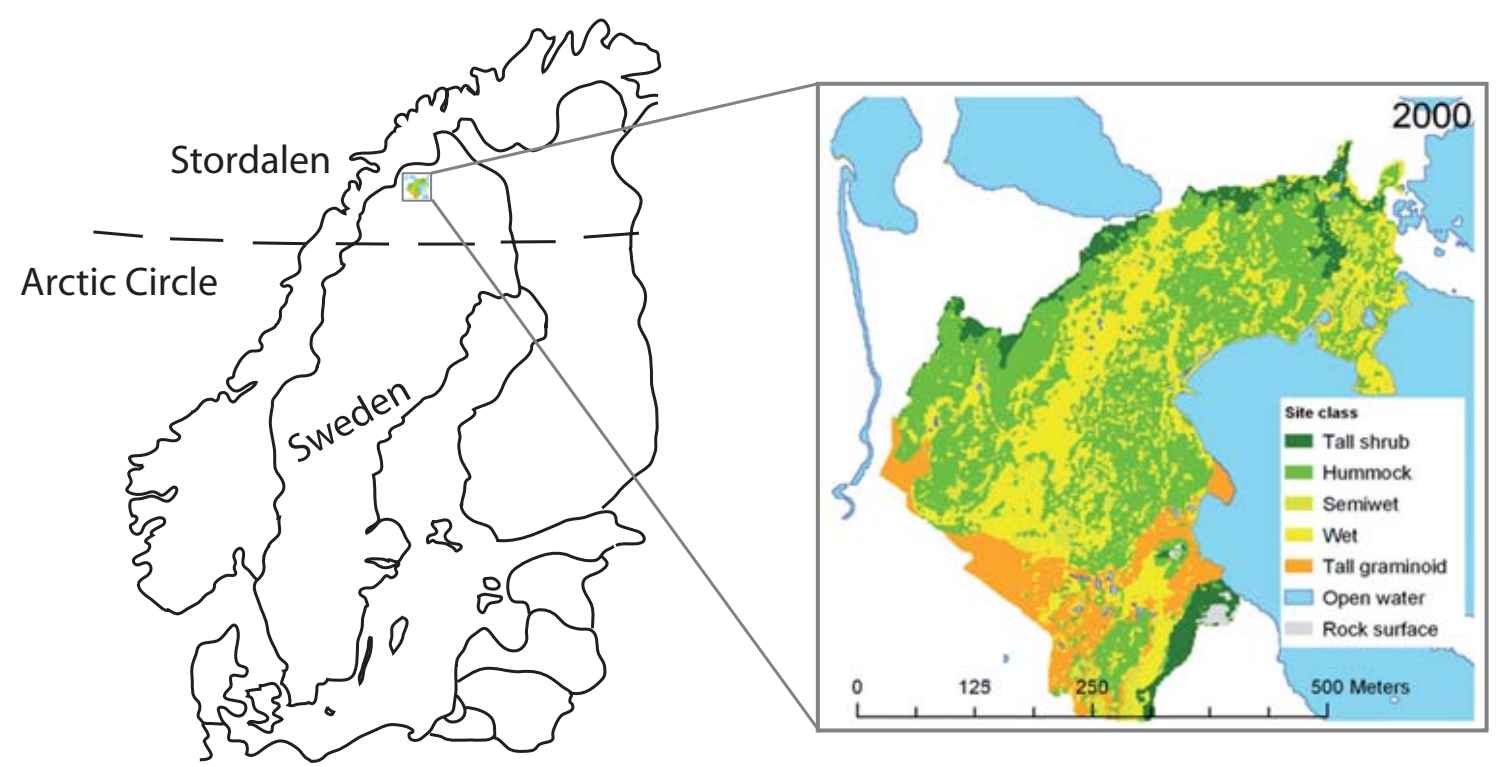

Fig. 1. Location map showing the position of the Stordalen mire in Northern Sweden $\left(68^{\circ} 22^{\prime} \mathrm{N}, 19^{\circ} 03^{\prime} \mathrm{E}\right)$ and also a vegetation map illustrating the highly variable plant community distribution at the mire (from Malmer et al., 2005). The Hummock class in the vegetation map corresponds to the Palsa site in this study, whereas the Semiwet and Wet classes corresponds to Sphagnum site and Tall graminoid class corresponds to Eriophorum site.

\section{Materials and methods}

\subsection{Study site}

Stordalen mire is located in Northern Sweden $\left(68^{\circ} 22^{\prime} \mathrm{N}\right.$, $\left.19^{\circ} 03^{\prime} \mathrm{E}\right), 10 \mathrm{~km}$ south east of Abisko and Abisko Scientific Research Station (ANS) (Fig. 1). The climate is subarctic with a mean annual temperature at ANS of $0.07^{\circ} \mathrm{C}$ with $308 \mathrm{~mm}$ of accumulated precipitation (20-year mean; 1986-2006). Stordalen is underlain by discontinuous permafrost, therefore localities nearby each other have a wide range of moisture and nutrient status which creates distinct differences in vegetation types (Malmer et al., 2005). Three distinct plant communities present at the mire are defined as those dominated by i) woody herbaceous vegetation on top of drained palsa areas (i.e. permafrost sites), ii) Sphagnum spp. and Carex spp. vegetation in the intermediate thaw features where the water table fluctuates close to the ground surface and iii) dense Eriophorum angustifolium in the wet areas where the ground thaws completely in the summer. Hereafter, they are referred to as the Palsa site, the Sphagnum site and the Eriophorum site. These three plant communities were chosen for the study because they capture the range of moisture and nutrient status in the mire and they are the three most common plant communities. Even though there are transition communities between the three types of sites sampled, these have been included into the three site defintions as defined in Johansson et al. (2006). Further detailed description of the three sites, including defined species names can be found in Bäckstrand et al. (2008ab).
Each site has differences in the active layer dynamics (AL; the top layer of the soil above the permafrost that freezes and thaws each year) and the water table position (WT). Fig. 2 shows the variation over an example year (2004) for AL and WT between the three sites as well as temperature and precipitation recorded at ANS.

\subsection{Automatic chamber measurements of $\mathrm{CO}_{2}$ and THC flux}

The automatic chamber system used to measure the $\mathrm{CO}_{2}$ and THC exchange has previously been described in detail (Bäckstrand et al., 2008a; Bäckstrand et al., 2008b). Briefly, is consists of 8 transparent Lexan ${ }^{\circledR}$ chambers positioned at the three sites ( 3 chambers at the Palsa site, 3 chambers at the Sphagnum site and 2 chambers at the Eriophorum site). Each chamber covers an area of $0.14 \mathrm{~m}^{2}(38 \mathrm{~cm} \times 38 \mathrm{~cm})$ with a height from $25-45 \mathrm{~cm}$ depending on the vegetation and depth of insertion. A lid is closed and opened automatically with a double acting pneumatic piston (Bimba Manufacturing Company, Illinois, USA) connected to a compressor (GAST Manufacturing Inc., Michigan, USA) by 1/8" nylon tubes. Each chamber was closed for 5 min every $3 \mathrm{~h}$. The chambers were connected to the associated analysis system, placed in a nearby heated cabin, by $3 / 8$ " Dekoron polypropylene lined and sheathed aluminum tubing through which air was circulated at a rate of $4 \mathrm{~L} \mathrm{~min}^{-1}$ during sampling. Sample air was circulated through a condensing water trap, a $0.4 \mu \mathrm{m}$ particle filter and then the air passed through a nondispersive $\mathrm{CO}_{2}$ analyzer. A flow of $1-5 \mathrm{~mL} \mathrm{~min}^{-1}$ was drawn 


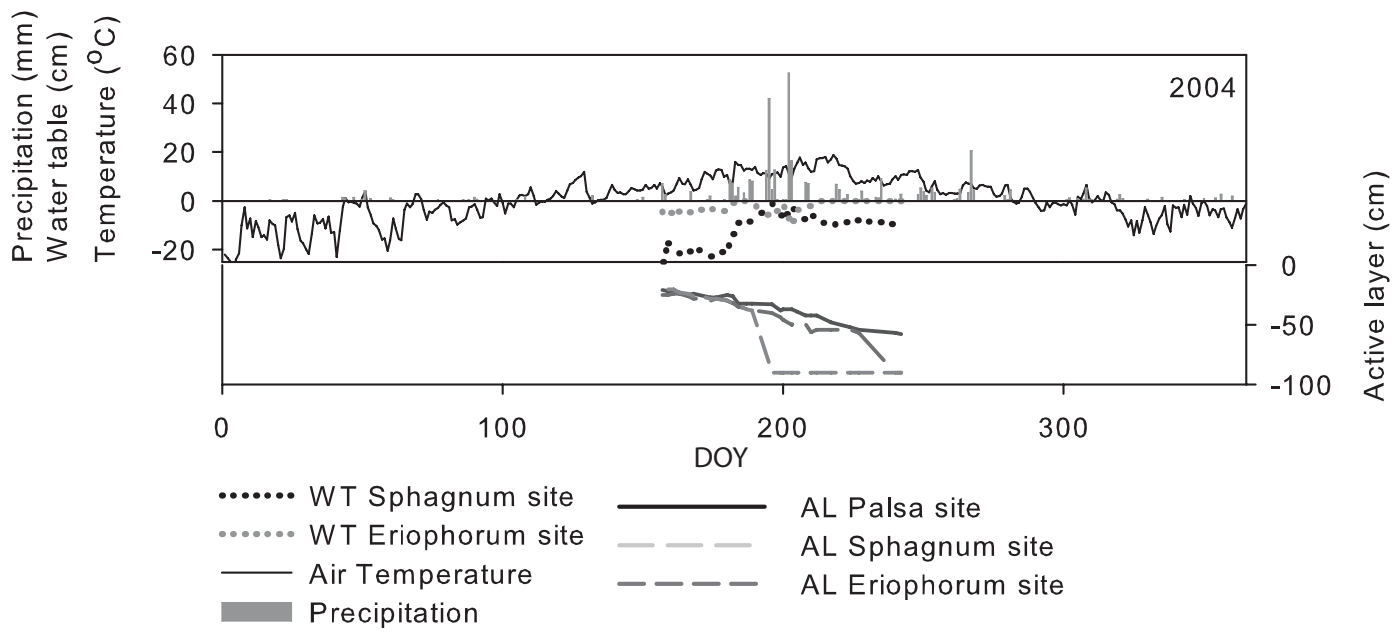

Fig. 2. One year of environmental parameters of water table (WT) and active layer (AL) show the differences in moisture and permafrost regimes at the three sites (Palsa, Sphagnum and Eriophorum) in the summer season. The annual temperature curve and green season precipitation data were collected at Abisko Scientific Research Station. DOY on the $\mathrm{x}$ axis stands for day of year.

Table 1. Sampling period for each year presented as day of year (DOY) for the first and last day of sampling. $\mathrm{CO}_{2}$ and THC coverage indicates number of days in $\%$ when data are available during the sampling period. $\mathrm{CO}_{2}$ and $\mathrm{THC}$ denote carbon dioxide and total hydrocarbon respectively.

\begin{tabular}{rrcc}
\hline Year & Sampling period & $\mathrm{CO}_{2}$ coverage $\%$ & THC coverage $\%$ \\
\hline 2002 & $84-147$ & 100 & 97 \\
2003 & $119-240$ & 96 & 70 \\
2004 & $147-329$ & 100 & 51 \\
2005 & $148-341$ & 47 & 79 \\
2006 & $123-234$ & 86 & 25 \\
2007 & $154-305$ & 97 & 55 \\
\hline
\end{tabular}

to the THC analyzer from the closed, main sample flow. Raw signals were acquired with a datalogger (CR10X Campbell Scientific Inc., Utah, USA) at a frequency of $3 \mathrm{~s}$ and averaged every $15 \mathrm{~s}$. THC and $\mathrm{CO}_{2}$ fluxes were calculated using a linear regression of change in the headspace mixing ratio with time during a period of $2.5 \mathrm{~min}$.

\subsection{Data coverage for specific years}

The data coverage for specific years is shown in Table 1. The table shows first and last day of sampling for each year. In between these days, there may be shorter or longer periods with no data collection. The number of days during the sampling period that are represented in the data set are accounted for as \% coverage in Table 1 . To again clarify coverage of snow season measurements, these have been conducted over a period of nearly 2 months before, and 1 months after the gap fill, while it is the period from 7 December to 25 March for which we have gap filled data.

\subsection{Environmental variables}

Active layer depth and water table position relative to ground surface that is presented in Fig. 2 were measured manually 3-5 times per week at all sites during the green season. Year around meteorological data of temperature and precipitation presented in Fig. 2 were recorded at ANS. Comparing the annual average temperature at Stordalen with that recorded at ANS, Stordalen is consistently $\sim 1{ }^{\circ} \mathrm{C}$ cooler (JackowiczKorczyñski et al., 2009).

\subsection{Data analyses}

We define the net carbon gas balance (NCB) as the sum of the oxidized $\left(\mathrm{CO}_{2}\right)$ and the reduced (THC; $\mathrm{CH}_{4}$ and NMVOCs) $\mathrm{C}$ compound gas fluxes. To calculate the NCB, both flux estimates of $\mathrm{CO}_{2}$ and THC fluxes are needed. There are more $\mathrm{CO}_{2}$ data than THC and therefore, the occasions when $\mathrm{NCB}$ has been possible to calculate are in the range of THC data points. Any potential exchange between land and atmosphere of carbon monoxide (CO) has not been captured by our measurements. A natural exchange between wetland environments and land can be present both as uptake and emission (Funk et al., 1994; Rich and King, 1998), but this gas component cannot be measured by the $\mathrm{CO}_{2}$ and THC analyzers adopted at our site.

Running means for $\mathrm{CO}_{2}$ and THC individual flux observations of approximately 3 days are calculated for each year separately (Fig. 3). They are based on 72 data points at the Palsa and Sphagnum sites (where 3 chambers are distributed at each site) and 48 data points at the Eriophorum site (where 2 chambers are positioned), where one data point represents an individual chamber flux measurement. 
Table 2. Statistics for flux data $\left(\mathrm{mgC} \mathrm{m}^{-2} \mathrm{~d}^{-1}\right)$ from the snow season ${ }^{1}$ and the green season ${ }^{1}$, each site analyzed separately. The reason why the mean NCB values are not simply the sum of $\mathrm{CO}_{2}$ and THC in Table 2 is because the two gas components' mean values are based on different number of flux measurements. $\mathrm{CO}_{2}$, THC, and NCB denote carbon dioxide, total hydrocarbons and net carbon gas balance, respectively.

\begin{tabular}{|c|c|c|c|c|c|c|c|c|c|c|c|}
\hline & \multirow[b]{2}{*}{ C component } & \multicolumn{5}{|c|}{ Snow season; Days 1-118/289-365 } & \multicolumn{5}{|c|}{ Green season; Days 119-288 } \\
\hline & & Mean flux & $\mathrm{SD}^{*}$ & Min & $\operatorname{Max}$ & $\mathrm{N}^{* *}$ & Mean flux & $\mathrm{SD}^{*}$ & Min & $\operatorname{Max}$ & $\mathrm{N}^{* *}$ \\
\hline \multicolumn{12}{|l|}{ Palsa site } \\
\hline & $\mathrm{CO}_{2} \mathrm{mgC} \mathrm{m}^{-2} \mathrm{~d}^{-1}$ & 291.6 & 551 & -651 & 8831 & 2081 & -184.0 & 1176 & -6649 & 12907 & 10596 \\
\hline & $\mathrm{THC} \mathrm{mgC} \mathrm{m}^{-2} \mathrm{~d}^{-1}$ & 0.5 & 2 & -7 & 29 & 999 & 2.0 & 6 & -9 & 113 & 5302 \\
\hline & $\mathrm{NCB} \mathrm{mgC} \mathrm{m}{ }^{-2} \mathrm{~d}^{-1}$ & 154.6 & 269 & -496 & 1272 & 999 & -177.1 & 1312 & -6641 & 12960 & 5300 \\
\hline \multicolumn{12}{|l|}{ Sphagnum site } \\
\hline & $\mathrm{CO}_{2} \mathrm{mgC} \mathrm{m}^{-2} \mathrm{~d}^{-1}$ & 73.1 & 136 & -501 & 1173 & 4159 & -318.2 & 927 & -31713 & 5885 & 21334 \\
\hline & THC $\mathrm{mgC} \mathrm{m}^{-2} \mathrm{~d}^{-1}$ & 11.5 & 6 & -11 & 53 & 2047 & 28.1 & 17 & 0 & 119 & 10686 \\
\hline & $\mathrm{NCB} \mathrm{mgC} \mathrm{m}^{-2} \mathrm{~d}^{-1}$ & 81.2 & 166 & -478 & 1185 & 2003 & -325.0 & 969 & -3848 & 3711 & 10618 \\
\hline \multicolumn{12}{|l|}{ Eriophorum site } \\
\hline & $\mathrm{CO}_{2} \mathrm{mgCm}^{-2} \mathrm{~d}^{-1}$ & 210.8 & 750 & -3987 & 5181 & 911 & -651.9 & 2151 & -12430 & 30996 & 8048 \\
\hline & THC $\mathrm{mgC} \mathrm{m}^{-2} \mathrm{~d}^{-1}$ & 78.2 & 32 & 13 & 234 & 212 & 119.4 & 76 & 0 & 636 & 4733 \\
\hline & $\mathrm{NCB} \mathrm{mgC} \mathrm{m} \mathrm{m}^{-2} \mathrm{~d}^{-1}$ & 727.7 & 889 & -1863 & 5294 & 190 & -728.7 & 2246 & -12198 & 4640 & 4733 \\
\hline
\end{tabular}

${ }^{1}$ Determined from camera at Stordalen (Svensson, 2004; Jackowicz-Korczyñski et al., 2009);

* Standard Deviation;

** Number of data points.

When yearly accumulated fluxes were calculated, we filled periods of missing data in the early (days 1-84) and late (days 342-365) year with snow season averages from Table 2. Because the data coverage is different for different years (Table 1), accumulated fluxes have been calculated by sorting all data from all years by time and day of year, independent on what year it was collected. By this approach, which incorporates the interannual variability into the mean, we create the longest period of data coverage in order to develop an average estimate based on several years of observations. Because the data coverage from each separate year sometimes differ from each other, it is not possible to explore the interannual variability over as long time periods as a year. The interannual variability of the green season THC fluxes has been discussed previously (Bäckstrand et al., 2008b).

In the case of the wet $\mathrm{CH}_{4}$ emitting sites, a global warming potential (GWP) factor of 25 (i.e. a 100 year perspective; Forster et al., 2007) has been used to estimate the THC emission as well as $\mathrm{NCB}$ in $\mathrm{CO}_{2}$ equivalents. It should be noted that only the average $\mathrm{CH}_{4}$ component of the THC flux at each site has been transformed into $\mathrm{CO}_{2}$ equivalents and the rest considered to be NMVOCs has not been assigned any GWP factor (approximately 25\% NMVOCs of THC at the Sphagnum site and $15 \%$ NMVOCs at the Eriophorum site on average in the green season; Bäckstrand et al., 2008a; 2008b). NMVOCs do have an indirect impact on the concentration of greenhouse gases and can be assigned a GWP factor according to IPCC (Forster et al., 2007). However, because of the uncertainties in these numbers and because of the fact that we have not specified specific NMVOC species in this study, we have chosen not to assign any GWP to the NMVOC com- ponent of THC. Further, the GWP of 25 has been applied to fluxes throughout the year even though the NMVOC contribution to THC likely can be considered close to zero during the snow season. However, because we have not estimated NMVOC contribution to THC for the snow season fluxes, we again chose to calculate the radiative forcing impact in a conservative way.

Definition of snow season (days 1-118 and 289-366) and green season (119-288) respectively has been conducted using a digital camera (visible part of the spectrum) at Stordalen. One photograph per day was taken throughout the years (Svensson, 2004; Jackowicz-Korczyñski et al., 2007, 2009). This results in an approximate snow season of 194 days while the green season is 171 days, i.e. 23 days longer snow season compared to green season. Because the division of the seasons is based on a larger scale picture of whether the mire was snow covered or not, it does not reflect the spatial variation of snow accumulation within the mire. The spatial variation is large and in general, it can be considered that the palsas most often are bare due to snow drift caused by wind, while the topographically lower positioned Sphagnum and Eriophorum sites are characterized by higher rates of snow accumulation. General snow depths have been reported to range between 0 and $10 \mathrm{~cm}$ on top of the palsas and between 10 and $60 \mathrm{~cm}$ in the deeper parts (Rydén and Kostov, 1980). 


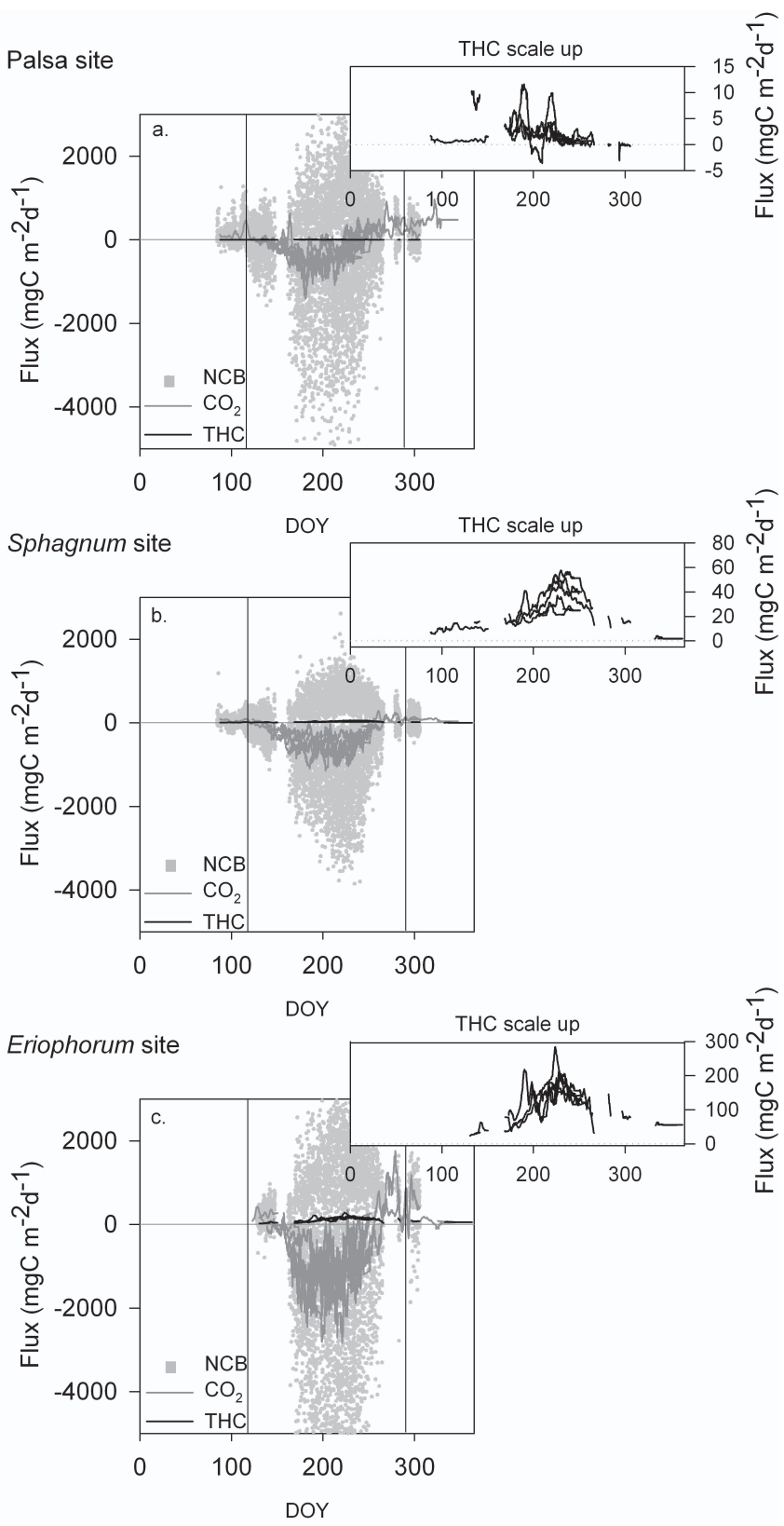

Fig. 3. Three day running mean of $\mathrm{CO}_{2}$ and $\mathrm{THC}$ presented as lines, and $\mathrm{NCB}$ (sum of $\mathrm{CO}_{2}$ and THC) estimates are presented as individual data points. Because the THC component measured in gram $\mathrm{C}$ is very small compared to $\mathrm{CO}_{2}$, the seasonal distribution of the NCB measurement points can be considered to also show the large scale seasonal variation for $\mathrm{CO}_{2}$. Positive numbers represent addition to the atmosphere and negative numbers represent loss from the atmosphere. The time period between vertical lines at DOY 119 and DOY 289 indicate the limit of the green season. DOY on the $x$ axes stands for day of year. All fluxes in $\mathrm{mgC} \mathrm{m}^{-2} \mathrm{~d}^{-1}$.

\section{Results}

\subsection{Seasonal dynamics of $\mathrm{C}$ gas flux components}

Individual chamber measurements of $\mathrm{CO}_{2}$ and $\mathrm{THC}$ have been plotted as 3 day running mean, each year plotted separately (Fig. 3). Calculated NCB, for those chamber closure times when both $\mathrm{CO}_{2}$ and THC were measured, is presented as individual data points. The numbers of flux measurements used in the analysis were 12677 and 6301 for $\mathrm{CO}_{2}$ and THC respectively at the Palsa site, $25493\left(\mathrm{CO}_{2}\right)$ and 12733 (THC) for the Sphagnum site and $8959\left(\mathrm{CO}_{2}\right)$ and 4945 (THC) for the Eriophorum site.

We analyzed the differences between the snow season fluxes and the fluxes measured during the green season (Table 2; Fig. 3). In Table 2, average fluxes are presented with standard deviation (sd). Please note that for $\mathrm{CO}_{2}$ fluxes, average number is based on both day and night measurements which results in that the standard deviation is large and gives a hint of the high diurnal variation caused by photosynthesis and respiration. The standard deviation is however not suitable for comparing differences between the sites with respect to average $\mathrm{CO}_{2}$ fluxes. In Bäckstrand et al (2008b), the differences between the sites were confirmed to be significant for both $\mathrm{CO}_{2}$ and THC. In the snow season, all sites were on average $\mathrm{C}$ sources of both $\mathrm{CO}_{2}$ and THC to the atmosphere, therefore the NCB was also positive, i.e. there was on average a net $\mathrm{C}$ input to the atmosphere. The average snow season $\mathrm{CO}_{2}$ and THC fluxes at the Palsa site were $291.6 \mathrm{mgC} \mathrm{m}^{-2} \mathrm{~d}^{-1}$ and $0.5 \pm 2 \mathrm{mgC} \mathrm{m}^{-2} \mathrm{~d}^{-1}$ (1sd; 999 samples) respectively. Corresponding fluxes at the Sphagnum site were $73.1 \mathrm{mgC} \mathrm{m}^{-2} \mathrm{~d}^{-1}$ for $\mathrm{CO}_{2}$, and $11.5 \pm 6 \mathrm{mgC} \mathrm{m}^{-2} \mathrm{~d}^{-1}$ (1sd; 2047 samples) for THC. For the Eriophorum site, snow season averages were $210.8 \mathrm{mgC} \mathrm{m}^{-2} \mathrm{~d}^{-1}$ for $\mathrm{CO}_{2}$ and $78.2 \pm 32 \mathrm{mgC} \mathrm{m}^{-2} \mathrm{~d}^{-1}$ (1sd; 212 samples) for THC. In contrast, all sites were on average sinks of $\mathrm{CO}_{2}$ and sources of THC in the green season. Due to a stronger $\mathrm{CO}_{2}$ sink function, the average NCB was negative, i.e. an average removal of $\mathrm{C}$ from the atmosphere as opposed to the snow season. The Palsa site had an average net uptake of $\mathrm{CO}_{2}$ that corresponds to $184.0 \mathrm{mgC} \mathrm{m}^{-2} \mathrm{~d}^{-1}$, while the average THC emission was $2.0 \pm 6 \mathrm{mgC} \mathrm{m}^{-2} \mathrm{~d}^{-1}$ (1sd; 5302 samples). At the Sphagnum site, the average $\mathrm{CO}_{2}$ sink function was greater representing an uptake of $318.2 \mathrm{mgC} \mathrm{m}^{-2} \mathrm{~d}^{-1}$, and also the average THC emission was greater, $28.1 \pm 17 \mathrm{mgC} \mathrm{m}^{-2} \mathrm{~d}^{-1}$ (1sd; $10686 \mathrm{sam}$ ples). The highest average $\mathrm{CO}_{2}$ uptake and the highest average THC emission were both found at the Eriophorum site, $651.9 \mathrm{mgC} \mathrm{m}^{-2} \mathrm{~d}^{-1}$ and $119.4 \pm 76 \mathrm{mgC} \mathrm{m}^{-2} \mathrm{~d}^{-1}(1 \mathrm{sd}$; 4733 samples) respectively. 
Table 3. The seasonal contribution ${ }^{\mathrm{a}}$ for each $\mathrm{C}$ component to the annual flux ${ }^{\mathrm{b}}$, in $\mathrm{gC}^{-2}$, separated into snow season, green season and annually. $\mathrm{CO}_{2}$, THC, and NCB denote carbon dioxide, total hydrocarbons and net carbon gas balance, respectively.

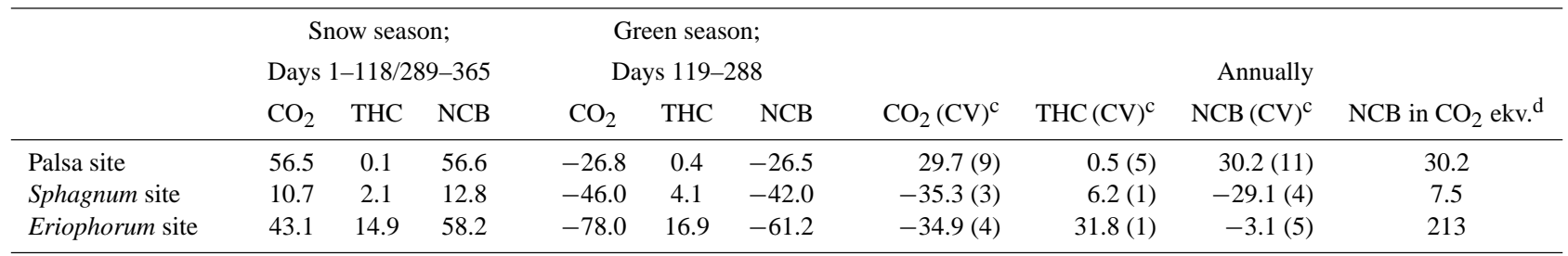

${ }^{a}$ Note that these numbers are arrived from the accumulated flux curves (Fig. 4), which in turn are based on data points when both THC and $\mathrm{CO}_{2}$ flux measurements were available, i.e. in the range of the THC data points and not from the overall average fluxes presented in Table 2.

${ }^{\mathrm{b}}$ For the Palsa and Sphagnum sites, $\mathrm{CO}_{2}$ data was filled for doy 1-84 and 330-365 while THC were filled for doy 1-84 and 305-365. At the Eriophorum site, $\mathrm{CO}_{2}$ data was filled for doy 1-127 and 330-365 while THC data was filled for doy 1-127 and 305-365.

${ }^{\mathrm{c}} \mathrm{CV}$; Estimated coefficient of variation, calculated for each site flux type (standard error/mean),

d A GWP factor of 25 was used for the $\mathrm{CH}_{4}$ component of THC (Forster et al., 2007).

\subsection{Annually accumulated estimates of $\mathbf{C}$ gas flux components}

Annually accumulated fluxes were estimated for each site, for which we filled periods of missing data in the early (days 1-84) and late (days 342-365) year with snow season averages arrived from Table 2 (also described in method section) (Fig. 4; Table 3). The length of the growing season, i.e. the period during which there is a continuous net $\mathrm{CO}_{2}$ uptake according to the accumulated fluxes, varied between the sites (Fig. 4). The Palsa site had a 110 day long growing season, starting on day 124 and ending on day 234. . The Sphagnum site had a longer growing season of 134 days lasting between day 118 and 234. At the Eriophorum site, the growing season was the shortest with 103 days, starting later than at the other sites on day 154 and lasting until day 257.

The whole year accumulated fluxes showed that the Palsa site was a $\mathrm{CO}_{2}$ source of $29.7 \mathrm{gC} \mathrm{m}^{-2}$ and also a small THC source of $0.5 \mathrm{gC} \mathrm{m}^{-2}$. Because the THC component was very small compared to the $\mathrm{CO}_{2}$, the $\mathrm{NCB}$ was positive and in the same range as $\mathrm{CO}_{2}$. This means that the Palsa site added $\mathrm{C}$ to the atmosphere over a year's time span (Table 3; Fig. 4a). The Sphagnum site was a $\mathrm{CO}_{2}$ sink of $35.3 \mathrm{gC} \mathrm{m}^{-2}$ while being a THC source of $6.2 \mathrm{gC} \mathrm{m}^{-2}$, but since the $\mathrm{CO}_{2}$ sink was stronger than the THC source, there was a negative NCB of $-29.1 \mathrm{gC} \mathrm{m}^{-2}$. This means that the Sphagnum site takes away $\mathrm{C}$ from the atmosphere on an annual basis (Table 3; Fig. 4b). The Eriophorum site was a $\mathrm{CO}_{2}$ sink of $34.9 \mathrm{gC} \mathrm{m}^{-2}$ and at the same time it was a THC source of $31.8 \mathrm{gC} \mathrm{m}^{-2}$. The NCB was therefore close to balanced by $-3.1 \mathrm{gC} \mathrm{m}^{-2}$, representing a small sink of atmospheric $\mathrm{C}$ over the course of a year (Table 3; Fig 4c). In Table 3, we also present an estimated coefficient of variation (CV), based on standard errors and the mean of all sampled fluxes for each site and $\mathrm{C}$ flux component. The CVs range between 1 and $11 \%$.
In Table 3, the seasonal contribution to the absolute sum of the annual flux for each of the $\mathrm{C}$ components is presented. In a similar way to the overall seasonal averages presented above, the results show that the snow season efflux of $\mathrm{CO}_{2}$ has a very strong impact on the annual $\mathrm{NCB}$, but also that the accumulated THC emission during the snow season contributes significantly to the annual THC efflux.

The amount of $\mathrm{C}$ as THC that is exchanged at the surface is often low compared to the mass of $\mathrm{C}$ as $\mathrm{CO}_{2}$. On the other hand, in terms of $\mathrm{CO}_{2}$ equivalents, the $\mathrm{CH}_{4}$ component which represents the larger part of THC at the wetter Sphagnum spp. (75\%) and Eriophorum spp. (85\%) vegetation communities at Stordalen has a strong warming potential in the atmosphere. The $\mathrm{CH}_{4}$ component is therefore important when considering an ecosystem's total short term radiative forcing capacity on climate. On a 100 year time span, $\mathrm{CH}_{4}$ is considered to have a 25 times more effective radiative forcing potential than $\mathrm{CO}_{2}$ (Forster et al., 2007). This results in the annual NCB at the Sphagnum and Eriophorum site shifting from being sinks of $\mathrm{C}$ measured in $\mathrm{gC} \mathrm{m}^{-2}$ to becoming much stronger atmospheric sources of $\mathrm{C}$ as $\mathrm{CO}_{2}$ equivalents and thereby also exerting a warming effect on climate (Table 3).

\subsection{Whole mire $\mathrm{C}$ gas balance}

Each vegetation community's annually accumulated flux per unit area is important to compare the flux ranges between different plant types and their physical environment, such as different moisture regimes and the presence or absence of permafrost. This comparison enables us to estimate how dynamic environmental changes such as disappearance of permafrost and shifted hydrological regimes might affect the $\mathrm{C}$ exchange. Extrapolating the plot scale measurements to estimate the whole Stordalen mire $\mathrm{C}$ fluxes require area estimates of each vegetation community. 

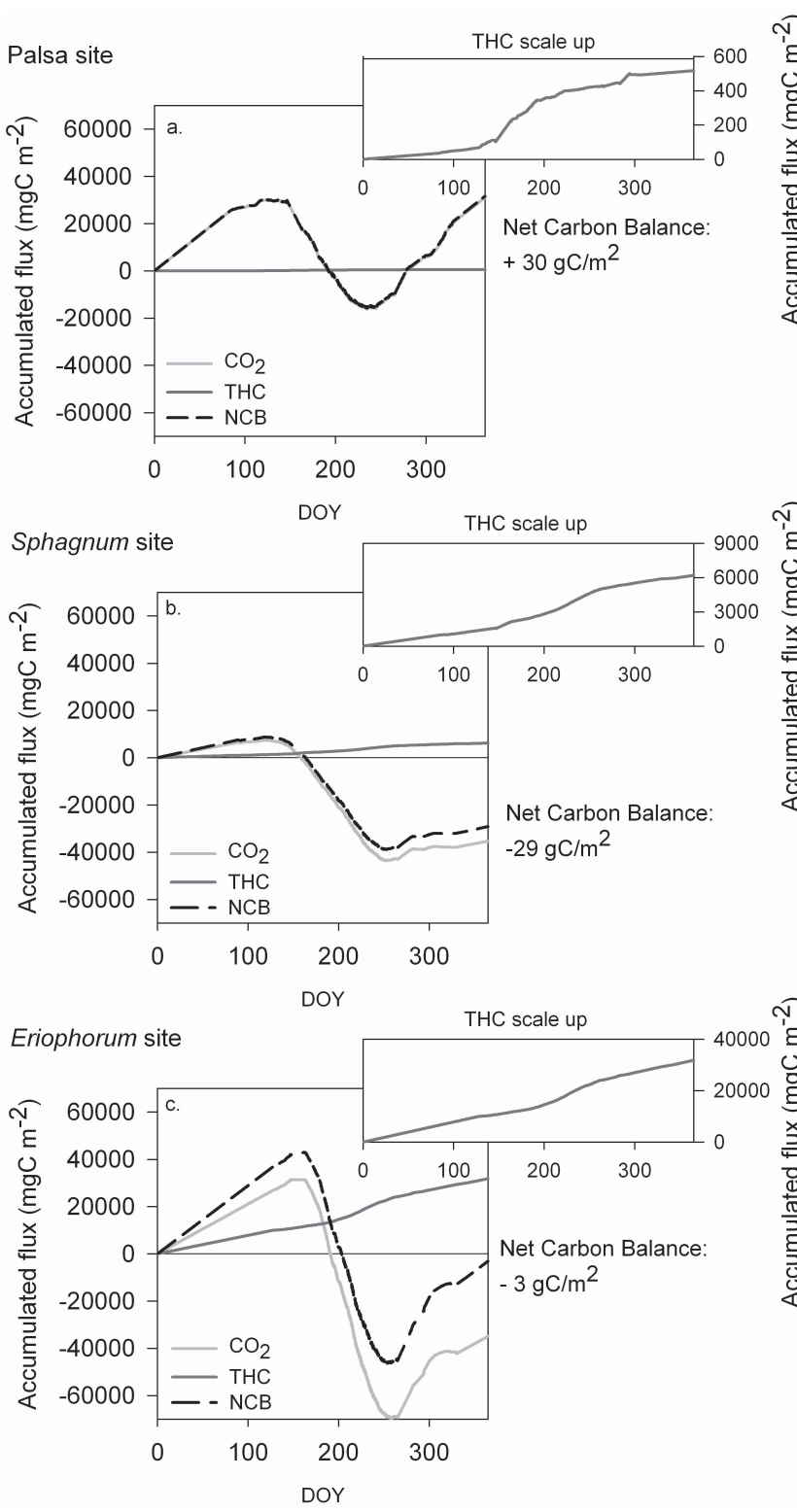

Fig. 4. Accumulated fluxes of $\mathrm{CO}_{2}$, THC and $\mathrm{NCB}$ where each site is presented separately. Positive numbers represent addition to the atmosphere and negative numbers represent loss from the atmosphere. DOY on the $\mathrm{x}$ axes stands for day of year. All fluxes in $\mathrm{mgC} \mathrm{m}^{-2}$.

The mire has a total area of 16.5 ha. Each vegetation type's area distribution on the mire was determined in 2000 (Table 4) (Malmer et al., 2005; Johansson et al., 2006). The Palsa, Sphagnum and Eriophorum sites have been estimated to cover 8.3 ha, 6.2 ha and 2.0 ha respectively (when the class Semiwet and Wet in Johansson et al., 2006b corresponds to the Sphagnum site in this study). By using the area estimates from these previous studies at Stordalen and combining them with the $\mathrm{C}$ fluxes measured in this study, the annual $\mathrm{C}$ gas exchange from the whole mire was estimated. It was calculated
Table 4. Area estimates of vegetation type distribution at the mire (from Johansson et al., 2006b ${ }^{1}$ ).

\begin{tabular}{lccc}
\hline & \multicolumn{3}{c}{ Area estimates (ha) } \\
Site & 1970 & 2000 & $\Delta \%$ \\
\hline Palsa & 9.2 & 8.3 & $-10 \%$ \\
Sphagnum & 6.0 & 6.2 & $+3 \%$ \\
Eriophorum & 1.3 & 2.0 & $+54 \%$ \\
\hline
\end{tabular}

1 Sphagum site area in this study accounts for the two vegetation classes Semiwet and Wet in Johansson et al., 2006.

that the whole mire is a $\mathrm{CO}_{2}$ sink of $425 \mathrm{kgC}\left(2.6 \mathrm{gC} \mathrm{m}^{-2}\right)$ and a THC source of $1063 \mathrm{kgC}\left(6.4 \mathrm{gC} \mathrm{m}^{-2}\right)$. Consequently, the calculations indicate that the mire is a net source of $\mathrm{C}$ to the atmosphere by $639 \mathrm{kgC}\left(3.9 \mathrm{gC} \mathrm{m}^{-2}\right)$ per year (Table 5). This means that the reduced $\mathrm{C}$ flux was sufficient to shift the mire from a sink to a source of $\mathrm{C}$ to the atmosphere over a year's time span.

By using area estimates of the mire vegetation distribution from 1970 as well as in 2000 (Johansson et al., 2006) (Table 4), it is possible to calculate a whole mire annual C gas budget and analyze how it has changed over the decades (Table 5). Regarding the NCB of the mire, it was estimated that the mire was a net $\mathrm{C}$ source of $990 \mathrm{kgC}$ in 1970 and this source strength had decreased to $639 \mathrm{kgC}$ by the year 2000 . Behind this decrease in source strength, we found increased net uptake of $\mathrm{CO}_{2}$. But there was also an increased net emission of THC and because the increase in THC consists mostly of $\mathrm{CH}_{4}$, the mire's radiative forcing capacity on climate has also increased substantially. When we take into account the $\mathrm{GWP}_{100}$ of the $\mathrm{CH}_{4}$ component of THC, we calculate that the mire's annual source function of net radiative forcing on climate increased by $21 \%$ over the three decades.

\section{Discussion}

\subsection{Seasonal dynamics of $\mathrm{C}$ gas flux components}

The most significant difference in the $\mathrm{C}$ flux dynamics when comparing the snow and green seasons was found relating to the $\mathrm{CO}_{2}$ dynamics. On average, as expected, we found positive fluxes of $\mathrm{CO}_{2}$ (i.e. emission) in the snow season and uptake in the green season (Table 2 and Table 3). Analyzing the standard deviations, it is found that the variability is greater in the green season reflecting the more pronounced diurnal variation including high photosynthetic rates during the day and more pronounced respiration during the night. In contrast, the variability in the snow season fluxes is less, likely because of cold temperatures and less little or no diurnal variation in lower light regimes at these high latitudes. The differences in THC emissions between the two seasons are not 
Table 5. Yearly accumulated fluxes for the whole mire in $\mathrm{kgC}$. Within brackets are whole mire area weighted fluxes in $\mathrm{gC}^{-2}$. The calculations are based on flux estimates from this study and area estimates from Johansson et al., 2006.

\begin{tabular}{lrrrl}
\hline & \multicolumn{3}{c}{ Yearly Accumulated fluxes from the whole mire in $\mathrm{kgC}\left(\mathrm{gC} \mathrm{m}^{-2}\right)$} \\
$\mathrm{C}$ component & 1970 & 2000 & $\Delta \mathrm{kgC}$ & \\
\hline $\mathrm{CO}_{2}$ & $157(0.95)$ & $-425(-2.6)$ & -582 & $\mathrm{CO}_{2}$ uptake increase \\
$\mathrm{THC}$ & $833(5.1)$ & $1063(6.4)$ & 230 & $\mathrm{THC}$ emission increase \\
$\mathrm{NCB}$ & $990(6.0)$ & $639(3.9)$ & -351 & decreased net $\mathrm{C}$ source function \\
$\mathrm{NCB}$ in $\mathrm{CO}_{2}$ eqv. $^{\mathrm{a}}$ & 5990 & 7222 & 1232 & increase in net radiative forcing \\
\hline
\end{tabular}

a A GWP factor of 25 was used for the $\mathrm{CH}_{4}$ component of THC (Forster et al., 2007).

as pronounced as for $\mathrm{CO}_{2}$ (Table 2 and Table 3). There is higher THC efflux in the green season compared to the snow season, again as expected. Factors such as higher temperatures, moisture and carbon substrate availability have previously explained higher emissions as well as spatial variability between vegetation communities in the THC emission rates (Ström and Christensen, 2007; Bäckstrand et al., 2008b). While the green season accounts for the highest THC flux, it is still important to notice the relatively high emissions in the winter.

While comparable growing season daily flux magnitudes previously have been reported between Stordalen and other sites (Christensen et al., 2004; Johansson et al., 2006; Bäckstrand et al., 2008b), it can now also be concluded that the winter fluxes measured at Stordalen also are comparable with other winter fluxes of oxidized and reduced $\mathrm{C}$ compounds measured at similar locations. Regarding average $\mathrm{CO}_{2}$ fluxes in the snow season measured at Stordalen, these ranged between 73.1 and $291.6 \mathrm{mgC} \mathrm{m}^{-2} \mathrm{~d}^{-1}$, with highest efflux at the Palsa site and lowest efflux at the Sphagnum site. This is a large variation between vegetation communities located nearby each other, and other studies reinforce the difficulties in projecting $\mathrm{CO}_{2}$ fluxes in the winter by showing a wide range of average daily fluxes. At a tundra wetland near Vorkuta, Russia, the reported range in wintertime $\mathrm{CO}_{2}$ flux was $14-27 \mathrm{mgC} \mathrm{m}^{-2} \mathrm{~d}^{-1}$ (Heikkinen et al., 2002a), at the boreal mire Degerö Stormyr in Northern Sweden the range was between 38 and $54 \mathrm{mgC} \mathrm{m}^{-2} \mathrm{~d}^{-1}$ (Sagerfors et al., 2008) and in Eastern Finland at several bog and fen sites, the efflux ranged from 167 to $478 \mathrm{mgC} \mathrm{m}^{-2} \mathrm{~d}^{-1}$ (Alm et al., 1997, 1999). On the subarctic flark fen in Kaamanen, Northern Finland, the average wintertime $\mathrm{CO}_{2}$ flux was presented as $130 \mathrm{mgC} \mathrm{m}^{-2} \mathrm{~d}^{-1}$ (Aurela et al., 2002) and at the boreal peatland Mer Bleu, Canada, the same number is around $390 \mathrm{mgC} \mathrm{m}^{-2} \mathrm{~d}^{-1}$ (Roulet et al., 2007).

Regarding the reduced $\mathrm{C}$ compound fluxes, the wetter sites at Stordalen had average snow season THC fluxes of $11.5 \mathrm{mgC} \mathrm{m}^{-2} \mathrm{~d}^{-1}$ and $78.2 \mathrm{mgC} \mathrm{m}^{-2} \mathrm{~d}^{-1}$ respectively for the Sphagnum and Eriophorum sites (Table 2) and these are also comparable to other sites' measurements. At bogs and fens in Finland, winter $\mathrm{CH}_{4}$ measurements revealed fluxes between 4 and $17 \mathrm{mgC} \mathrm{m}^{-2} \mathrm{~d}^{-1}$ (Alm et al., 1999). At a tundra wetland near Vorkuta, Russia, the winter fluxes of $\mathrm{CH}_{4}$ were in the range $11 \mathrm{mgC} \mathrm{m}^{-2} \mathrm{~d}^{-1}$ to $48 \mathrm{mgC} \mathrm{m}^{-2} \mathrm{~d}^{-1}$ (Heikkinen et al., 2002a). Vaisjeäggi in Finland had lower $\mathrm{CH}_{4}$ fluxes around $5 \mathrm{mgC} \mathrm{m}^{-2} \mathrm{~d}^{-1}$ (Nykänen et al., 2003) while the minerotrophic fen Siikaneva had winter fluxes reaching up to $24 \mathrm{mgC} \mathrm{m}^{-2} \mathrm{~d}^{-1}$ (Rinne et al., 2007). A likely possible explanation to the relatively high THC emissions in the winter is continuous $\mathrm{CH}_{4}$ production, however small, and degassing of $\mathrm{CH}_{4}$ from deeper peat layers that are not frozen. Earlier studies at Stordalen and the thaw-freeze cycles at the mire have shown that the frost front starts at the peat surface around October and deepens during the winter, but it rarely reaches the permafrost layer in the intermediate thaw sites at the mire (Rydén and Kostov, 1980). In areas where there is no permafrost, the ground still freezes from the top and downwards from the beginning of the winter. Also here, there is a potential thick layer of unfrozen peat that can support continuing methanogenesis and degassing during winter. The onset, depth and maintenance of snow cover will be critical to the peat frost dynamics and will play an important role in interannual variability of the fluxes.

It can be hypothesized that the snow season's importance for the annual $\mathrm{C}$ budget is greater at peatland locations located at high latitudes where there is a shorter green season and longer snow season. Because of the significant snow season emissions, it is recommended that this season is considered as important as the green season regarding measurement campaigns. By excluding this period from the annual budgets, an underestimation of the peatlands' C source strength is likely. The fact that other studies show snow season emission of $\mathrm{CO}_{2}$ and $\mathrm{CH}_{4}$ that is comparable with our measurements gives support for the use of our snow season averages to "gap fill" periods during which no data collections were made. 
Table 6. Compilation of annual net carbon balances $\left(\mathrm{NCB}\right.$ in $\mathrm{gC} \mathrm{m}^{-2}$ ) for northern mires where the exchange of both $\mathrm{CO}_{2}$, $\mathrm{CH}_{4}$ and sometimes NMVOCs and DOC/DIC leaching are represented in the $\mathrm{C}$ balance estimation. All units in $\mathrm{gC} \mathrm{m}^{-2}$. If the $\mathrm{CO}_{2}$ and $\mathrm{CH}_{4}$ components are not specified in the table, this information could not be revealed from the specific reference.

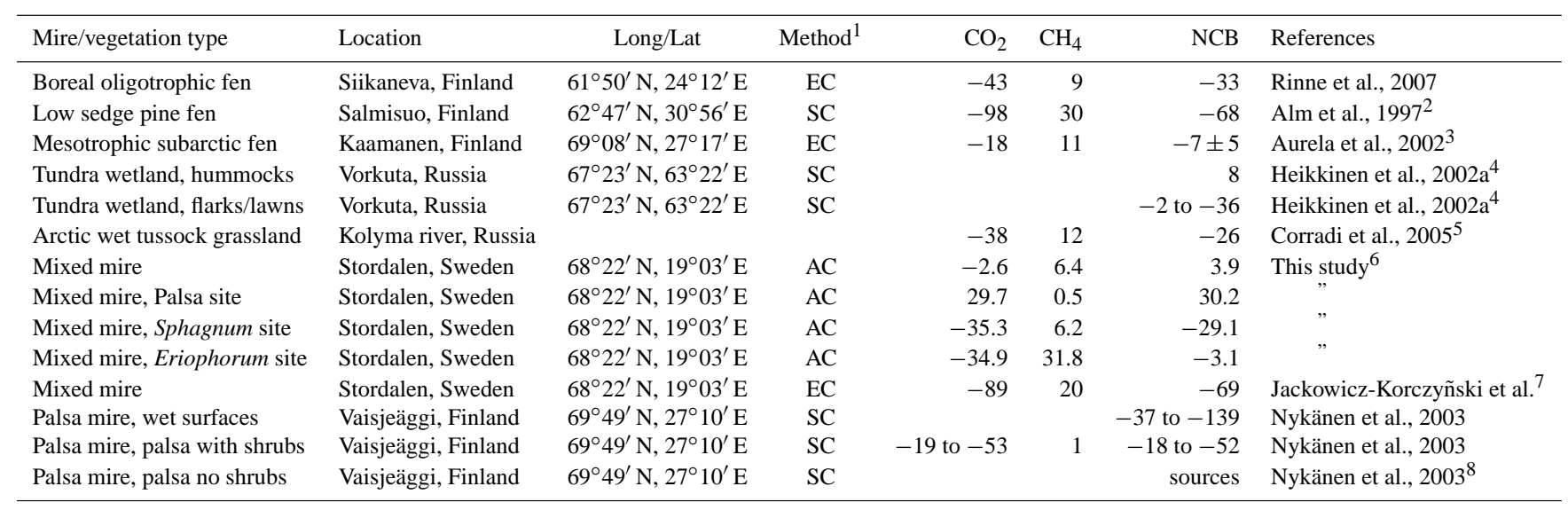

${ }^{1}$ Method as indicated: EC (eddy covariance), SC (static chambers), AC (automatic chambers).

${ }^{2} \mathrm{CH}_{4}$ estimate includes DOC/DIC leaching by $8 \mathrm{gC} \mathrm{m}^{-2}$.

${ }^{3} \mathrm{CH}_{4}$ estimate includes DOC/DIC leaching.

${ }^{4}$ Includes a loss of DOC/DIC leaching by $5 \mathrm{gC} \mathrm{m}^{-2}$.

${ }^{5} \mathrm{CH}_{4}$ emissions assumed only in July and August.

${ }^{6} \mathrm{CH}_{4}$ estimate includes NMVOCs.

${ }^{7} \mathrm{CO}_{2}$ flux estimate is a seven year average (2001-2007) while $\mathrm{CH}_{4}$ flux is a two year average (2006-2007). Manuscript submitted.

8 Source strength not specified.

\subsection{Annually accumulated estimates of $\mathrm{C}$ gas flux components}

There are only few estimates of annual $\mathrm{C}$ gas budgets around the Arctic that include both $\mathrm{CO}_{2}$ and hydrocarbon components (either or both $\mathrm{CH}_{4}$ and NMVOCs). The studies that have been presented also show large variation and there are, as always, limitations in the data sets because of missing snow season periods and different ways of gap filling. However, a comparison among this study at Stordalen and other estimates of the annual $\mathrm{C}$ gas balance reveals some significant patterns. Table 6 illustrates that all sites that show positive annual NCB, meaning that they are sources of $\mathrm{C}$ to the atmosphere on an annual basis, are palsa or hummock areas. Among the examined studies, the net $\mathrm{C}$ source strengths reach $30 \mathrm{gC} \mathrm{m}^{-2}$. Among the sites that are net $\mathrm{C}$ sinks, ranging from an uptake of $2 \mathrm{gC} \mathrm{m}^{-2}$ to an uptake of $139 \mathrm{gC} \mathrm{m}^{-2}$, are all characterized by being wet peatland/vegetation types. In these environments, the $\mathrm{CH}_{4}$ component is very important. When compared to the net amount of $\mathrm{C}$ exchange (both $\mathrm{CO}_{2}$ and $\mathrm{CH}_{4}$ ), the $\mathrm{CH}_{4}$ component accounts for $15-48 \%$ (the Stordalen mire estimate excluded). The only study where the NCB is positive as a result of higher net THC emissions than net $\mathrm{CO}_{2}$ uptake is at the Stordalen mire. The area weighted yearly accumulated fluxes from the whole mire $(16.5 \mathrm{ha})$ resulted in a positive annual $\mathrm{NCB}$, a release of $\mathrm{C}$ to the atmosphere at about $3.9 \mathrm{gC} \mathrm{m}^{-2}$, based on a net uptake of $\mathrm{CO}_{2}$ by $2.5 \mathrm{gC} \mathrm{m}^{-2}$ and an emission of THC by
$6.4 \mathrm{gC} \mathrm{m}^{-2}$ (Table 3). The factor behind this differential relationship between $\mathrm{CO}_{2}$ and THC at Stordalen compared to the other sites seems to be that the net $\mathrm{CO}_{2}$ uptake is much lower at Stordalen compared to other sites, while the $\mathrm{CH}_{4}$ /THC emissions are more similar between sites. Differences in productivity between sites cannot, however, be explained in any simply way such as for example latitudinal position and consequently length of growing season. Other sites are positioned at the same latitude, and the climate conditions between the sites vary and cannot be compared by simple means like reviewing literature. Differences in productivity may be due to different area distributions and density of specific vegetation communities. However, from the comparison between the studies presented in Table 6 , one can conclude that it is only in the wetter, often more nutrient rich mire/vegetation types that the amount of $\mathrm{CH}_{4} / \mathrm{THC}$ (in weight $\mathrm{C}$ measured) had a significant impact on the NCB.

The results of the $\mathrm{C}$ fluxes measured with the automatic chambers at Stordalen can now also be compared to $\mathrm{CH}_{4}$ fluxes measured with an eddy covariance (EC) system at the same mire (Jackowicz-Korczyñski et al.,2009). Taking into account wind conditions and vegetation class coverage, it was possible for the EC system to derive the emission signal originating from the Sphagnum and Eriophorum vegetation type communities. To avoid comparing time periods with scarcer data density (i.e. assumed and modeled data in the winter time), the summer period between days 154 and 249 was chosen for comparison between the two methodologies 
because of the high data density from both studies. During this period, the EC tower recorded $\mathrm{CH}_{4}$ emissions of $9 \mathrm{gC} \mathrm{m}^{-2}$ (Jackowicz-Korczyñski et al., 2009). By applying the accumulated fluxes from the chamber data to the vegetation community areas arrived from the tower footprint, it results in area weighted accumulated $\mathrm{CH}_{4}$ flux of $5 \mathrm{gC} \mathrm{m}^{-2}$ for the same period $\left(6 \mathrm{gC} \mathrm{m}^{-2}\right.$ of THC). The most probable reason for the difference is that the $\mathrm{EC}$ measurements capture larger amounts of $\mathrm{CH}_{4}$ ebullition from the wettest fen part of the mire. Ebullition has been shown to support a large amount of $\mathrm{CH}_{4}$ emitted from wetland and lakes (Christensen et al., 2003; Bastviken et al., 2004; Walter et al., 2006, 2007), but the automatic chamber system cannot capture these fluxes. It is also likely that the tower captures higher emissions during windy conditions compared to the chambers, a factor that has been documented in these and other studies (Wille et al., 2008; Jackowicz-Korczyñski et al., 2009).

\subsection{Thawing permafrost, resulting vegetation changes and their implications for the annual $\mathrm{C}$ gas balance}

The vegetation changes that have occurred at Stordalen over the last decades as a result of thawing permafrost are characterized by receding palsa areas and increased wetter vegetation communities (Malmer et al., 2005). These changes in vegetation and the physical environment consequently have implications for the whole mire $\mathrm{C}$ dynamics. Some of these flux changes have been presented before based on less frequently collected manual data and focusing on the growing season (Christensen et al., 2004; Johansson et al., 2006). This study can be seen as complement to and an update of former studies, particularly for the one by Johansson et al. (2006), now incorporating more years of data (including higher frequency measurements of the reduced $\mathrm{C}$ compounds), as well as taking into account the longer snow season period with much lower air temperatures. In a similar way to Johansson et al. (2006), we assume that the annual $\mathrm{C}$ exchange from a specific subhabitat has not changed over time, which makes it possible to use the same exchange rates per unit area. The uncertainties for our results also lie in the precision in the area distribution for each vegetation community, as the mire is very heterogeneous with respect to plant types and environmental factors.

We find that the whole mire has had an increased $\mathrm{CO}_{2}$ uptake in 2000 compared to 1970 (Table 5). In 1970, the annual $\mathrm{CO}_{2}$ exchange was estimated to be positive, $157 \mathrm{kgC}$, but with the subhabitat distribution measured in 2000, the whole mire is calculated to be a net sink of $\mathrm{CO}_{2}$ by $425 \mathrm{kgC}$. The change represents an almost 3 times stronger $\mathrm{CO}_{2}$ sink function than the source strength in 1970. This is due to the calculated expansion of thawed peat areas similar to the Sphagnum and Eriophorum subhabitats which are more productive during the growing season than the palsas, thereby increasing the ecosystem's capacity for $\mathrm{CO}_{2}$ uptake. Also, the respiration during the winter is less at the Sphagnum and Eriophorum site, and higher at the palsa site, further amplifying the possibility for an overall negative $\mathrm{CO}_{2}$ flux at the mire. According to our results, the vegetation changes have also brought increased THC emissions by $230 \mathrm{kgC}$ per year, representing an increase of $28 \%$ (Table 5). Both the Sphagnum and Eriophorum sites are high THC emitting environments, while the Palsa is not. In conclusion, it was estimated that the mire was a net source of $\mathrm{C}$ three decades ago, and still is today, but the total $\mathrm{C}$ source function has decreased by $35 \%$ (Table 5). In contrast, the mire's $\mathrm{NCB}$ in $\mathrm{CO}_{2}$ equivalents has increased net radiative forcing on climate by $21 \%$.

The $16 \%$ increase in the mire's $\mathrm{CO}_{2}$ sink function over the three decades that was found for the 153 day long growing season in the previous study (Johansson et al., 2006) was a result similar to the annual estimates from this study (from $0.95 \mathrm{gC} \mathrm{m}^{-2}$ in 1970 to $-2.6 \mathrm{gC} \mathrm{m}^{-2}$ in 2000$)$. The even higher strength in the sink function that is seen in the annual numbers when going from 1970 to 2000 is likely to be due to the incorporation of the snow season flux data. In the snow season, all sites are on average sources of $\mathrm{CO}_{2}$ to the atmosphere, and also annually, the Palsa site is a $\mathrm{CO}_{2}$ source. Therefore, the decrease in area extent of an annual $\mathrm{CO}_{2}$ source (palsa areas) in favor of vegetation communities being annual $\mathrm{CO}_{2}$ sinks (wetter areas) lead to this shift from the mire being a source of $\mathrm{CO}_{2}$ in 1970 to a sink of $\mathrm{CO}_{2}$ in 2000. The two studies further confirm that the estimates of increased reduced $\mathrm{C}$ compound emissions are similar, $22 \%$ and $28 \%$ for the growing season and annual budget respectively. If only using green season data, there is a risk of underestimating the decadal change as the snow season has been found to be an important $\mathrm{C}$ source period. When comparing the estimates for increase in radiative forcing on the atmosphere, which is $47 \%$ accounting for the growing season (Johansson et al., 2006) and $21 \%$ for the annual budget (this study), the difference is likely to be due to the fact that the $\mathrm{CH}_{4}$ component as $\mathrm{CO}_{2}$ equivalents have a higher impact when analyzed over only the growth period as compared to an annual basis.

Concerning the whole mire budgets presented for Stordalen in this study, it should be considered that the calculations are based on vegetation community distributions in 1970 and 2000. Because it is now nearly a decade later, 2008 , and a continuous collapse of palsa margins can be detected from year to year along with deepened hollows in the palsa ridges, it is very much likely that the expansion of the wetter areas has continued and that the palsa areas have receded even more. This implies a likelihood that the mire's productivity and net $\mathrm{CO}_{2}$ uptake have increased along with the expanding wetter areas, but also that the mire's radiative forcing on climate has intensified along with the increased proportion of high $\mathrm{CH}_{4}$ emitting environments.

Beyond the scope of this paper but closely related to the changes in the $\mathrm{C}$ gas dynamics as a result of the receding palsas, are likely changes in the export of DIC, DOC and 
POC (Jonsson et al., 2003; Guo et al., 2004; Roulet et al., 2007; van Dongen et al., 2008). The export of DOC may potentially increase as permafrost thaws and releases DOC into the hydrological system. Collapsing palsa margins, suddenly and in potentially very large amounts, increase the erosion derived concentration of POC. Both DIC, DOC and POC export contribute to the diminishing of the total mire $\mathrm{C}$ stock, and it is important to incorporate these components in the total mire $\mathrm{C}$ budget. This also includes incorporating the surrounding lake and river fluxes to understand where in the system these $\mathrm{C}$ components will go in the future, for example being deposited in the sediments on the lake bottom or decomposed within the lakes and emitted as $\mathrm{CO}_{2}$ or $\mathrm{CH}_{4}$ from the lake surfaces. Terrestrial $\mathrm{C}$ export at Stordalen for the year of 2005 has been estimated to $9.5 \mathrm{gC} \mathrm{m}^{-2}$, where approximately half of this is estimated to be emitted from the lake surface as $\mathrm{CO}_{2}$ and/or $\mathrm{CH}_{4}$, i.e. approximately $5 \mathrm{gC} \mathrm{m}^{-2}$ lake surface and year (J. Karlsson, personal communication, 2008). Other studies report DOC/DIC export rates between 5 and $15 \mathrm{gC} \mathrm{m}^{-2}$ at similar environments (Alm et al., 1997; Heikkinen et al., 2002a; Roulet et al., 2007). If we apply the annual terrestrial $\mathrm{C}$ export number of $9.5 \mathrm{gC} \mathrm{m}^{-2}$ as determined from Stordalen studies and the lake Abborrtjärn (J. Karlsson, personal communication, 2008) to our area weighted NCB of the whole mire which is $3.87 \mathrm{gC} \mathrm{m}^{-2}$, the annual loss from the mire is more than three times greater. By adding the net $\mathrm{C}$ emission from the lake surface of $5 \mathrm{gC} \mathrm{m}^{-2}$ at Stordalen (J. Karlsson, personal communication, 2008), also having been identified at other lakes (e.g. (Bastviken et al., 2004; Walter et al., 2007), the net loss from the mire and lake together is further reinforced.

\section{Conclusions}

Peatland environments are generally highly heterogeneous environments, which creates large uncertainties when it comes to understanding the resulting effects of dynamic processes such as permafrost thaws in these areas. Different peatlands have been shown to respond differently to thawing permafrost. For example, hydrological responses have been highly variable between sites, sometimes causing drier (Billings et al., 1982; Oechel et al., 1995; Oechel et al., 2000a) and sometimes causing wetter (Zuidhoff and Kolstrup, 2000; Jorgenson et al., 2001; Luoto et al., 2004) peatlands. This in turn exerts a strong control on plant community structure and $\mathrm{C}$ dynamics which clearly have been shown in this study and the comparison between the three sites with varying moisture and permafrost regimes. The uncertainties induced by the heterogeneity limit the scaling of plot scale data to ecosystem and global levels even to the point of having a common understanding of whether or not Arctic and subarctic peatlands can be considered to be consistent sinks or sources of C. However, this study among other estimates of specific peatlands' net $\mathrm{C}$ balances, finds that these environments possibly are at, or near, a change going from sink to source of $\mathrm{C}$ exchange. What we also can conclude from the Stordalen data, is that this specific mire has undergone environmental changes due to permafrost thaw which have had implications for the annual $\mathrm{C}$ balance, and most importantly, the net radiative forcing on climate. From our results, we can also point out the importance of wintertime measurements to fully understand the annual dynamics of the peatland $\mathrm{C}$ fluxes. The snow seasons can be important $\mathrm{C}$ source periods and by excluding this time of the year from the measurement campaigns, the $\mathrm{C}$ source strength of peatlands is possibly underestimated. Further, by showing that the reduced $\mathrm{C}$ compounds flux was sufficient to shift the whole mire from a sink to a source of $\mathrm{C}$ to the atmosphere over a year's time span, the importance of combining these $\mathrm{C}$ components for a better understanding of the $\mathrm{C}$ balance has been proven once again.

Acknowledgements. The research was supported by the Swedish research council (VR) and the Swedish STINT by grants to PMC. The Abisko Scientific Research Station, the Göran Gustafsson Foundation and K \& A Wallenberg Foundation have supported the work with stipends to $\mathrm{KB}$. We also thank the director Terry Callaghan of Abisko Scientific Research Station and all other personnel for their help during the field seasons. Andy Mosedale of A. M. Environmental Automation and Control helped in the construction of the chamber system. This long data set exists only due to cooperation in field and we are greatly thankful to J. Förster, P. Jaconelli, T. Johansson, V. Karlén, M. Lund, E. Norbäck, L. Ström, C. Thunell, M. Waara and M. Wiik for invaluable assistance in field. We are also thankful to J. Karlsson and his research team for sharing data on dissolved $\mathrm{C}$ and lake fluxes at Stordalen.

Edited by: A. Lindroth

\section{References}

Alm, J., Talanov, A., Saarnio, S., Silvola, J., Ikkonen, E., Aaltonen, H., Nykänen, H., and Martikainen, P. J.: Reconstruction of the carbon balance for microsites in a boreal oligotrophic pine fen, Finland, Oecologia, 110, 423-431, 1997.

Alm, J., Saarnio, S., Nykänen, H., Silvola, J., and Martikainen, P. J.: Winter $\mathrm{CO}_{2}, \mathrm{CH}_{4}$ and $\mathrm{N}_{2} \mathrm{O}$ fluxes on some natural and drained boreal peatlands, Biogeochemistry, 44, 163-186, 1999.

Aurela, M., Laurila, T., and Tuovinen, J. P.: Annual $\mathrm{CO}_{2}$ balance of a subarctic fen in Northern Europe: Importance of the wintertime efflux, J. Geophys. Res., 107, 1-12, doi:10.1029/2002JD002055, 2002.

Bäckstrand, K., Crill, P., Mastepanov, M., Christensen, T. R., and Bastviken, D.: Nonmethane volatile organic compound flux from a subarctic mire in Northern Sweden, Tellus B, 60B, 226-237, 2008a.

Bäckstrand, K., Crill, P., Mastepanov, M., Christensen, T. R., and Bastviken, D.: Total hydrocarbon flux dynamics at a subarctic mire in Northern Sweden, J. Geophys. Res., 113, 1-16, doi:10.1029/2008JG000703, 2008b. 
Bastviken, D., Cole, J., Pace, M., and Tranvik, L.: Methane emissions from lakes: Dependence of lake characteristics, two regional assesments, and a global estimate, Glob. Biogeochem. Cy., 18, 1-12, doi:10.1029/2004GB002238, 2004.

Billings, W. D., Luken, J. O., Mortensen, D. A., and Peterson, K. M.: Arctic Tundra - a Source or Sink for Atmospheric CarbonDioxide in a Changing Environment, Oecologia, 53, 7-11, 1982.

Christensen, T. R., Panikov, N., Mastepanov, M., Joabsson, A., Stewart, A., Oquist, M., Sommerkorn, M., Reynaud, S., and Svensson, B.: Biotic controls on $\mathrm{CO} 2$ and $\mathrm{CH} 4$ exchange in wetlands - a closed environment study, Biogeochemistry, 64, 337354, 2003.

Christensen, T. R., Johansson, T. R., Akerman, H. J., Mastepanov, M., Malmer, N., Friborg, T., Crill, P., and Svensson, B. H.: Thawing sub-arctic permafrost: Effects on vegetation and methane emissions, Geophys. Res. Lett., 31, L04501, doi:10.1029/2003GL018680, 2004.

Corradi, C., Kolle, O., Walter, K., Zimov, S. A., and Schulze, E. D.: Carbon dioxide and methane exchange of a north-east Siberian tussock tundra, Glob. Change Biol., 11, 1910-1925, doi:10.1111/j.1365-2486.2005.01023.x, 2005.

Crill, P., Bartlett, K., and Roulet, N.: Methane flux from boreal wetlands, Suo, 43, 173-182, 1992.

Ekberg, A., Arneth, A., Bäckstrand, K., Crill, P. M., Hakola, H., and Stark, H.: BVOC emissions from high-latitude peatlands: Isoprene and monoterpene fluxes in plant communities defined by differences in surface hydrology, Geophys. Res. Abstracts Vol. 10 EGU General Assembly, Wienna, Abstract A-04194, 2008.

Forster, P., Ramaswamy, V., Artaxo, P., Berntsen, T., Betts, R., Fahey, D. W., Haywood, J., Lean, J., Lowe, D. C., Myhre, G., Nganga, J., Prinn, R., Raga, G., Schulz, M., and Van Dorland, R.: Changes in atmospheric constituents and in radiative forcing, Cambridge University Press Cambridge, United Kingdom and New York, NY, USA, 2007.

Frolking, S., Roulet, N., Moore, T., Lafleur, P. M., Bubier, J., and Crill, P.: Modeling seasonal to annual carbon balance of Mer Bleue Bog, Ontartio Canada, Glob. Biogeochem. Cy., 16, 1-21, doi:10.1029/2001GB001457, 2002.

Funk, D. W., Pullman, E. R., Peterson, K. M., Crill, P. M., and Billings, W. D.: Influence of water table on carbon dioxide, carbon monoxide, and methane fluxes from taiga bog microcosms, Glob. Biogeochem. Cy., 8, 271-278, 1994.

Gorham, E.: Northern Peatlands - Role in the Carbon-Cycle and Probable Responses to Climatic Warming, Ecol. Appl., 1, 182195, 1991.

Guo, L., Semiletov, I., Gustafsson, Ö., Ingri, J., Andersson, P., Dudarev, O., and White, D.: Characterization of Siberian Arctic coastal sediments: Implications for terrestrial organic carbon export, Glob. Biogeochem. Cy., 18, GB1036, doi:10.1029/2003GB002087, 2004.

Heikkinen, J. E. P., Elsakov, V., and Martikainen, P. J.: Carbon dioxide and methane dynamics and annual carbon balance in tundra wetland in NE Europe, Russia, Glob. Biogeochem. Cy., 16(4), 1115, doi:10.1029/2002GB001930, 2002a.

Heikkinen, J. E. P., Maljanen, M., Aurela, M., Hargreaves, K. J., and Martikainen, P. J.: Carbon dioxide and methane dynamics in a sub-Arctic peatland in Northern Finland, Polar Res., 21, 49-62, $2002 b$.
Heikkinen, J. E. P.: Carbon balance of the Arctic wetlands in Europe, $\mathrm{PhD}$, Department of Environmental Science, University of Kuopio, Kuopio, 2003.

Heyer, J., Berger, U., Kuzin, I. L., and Yakovlev, O. N.: Methane emissions from different ecosystem structures of the subarctic tundra in Western Siberia during midsummer and during the thawing period, Tellus B, 54, 231-249, 2002.

Jackowicz-Korczyñski, M., Christensen, T. R., Bäckstrand, K., Crill, P., Friborg, T., Mastepanov, M., and Ström, L.: Annual cycles of methane emissions from a subarctic peatland, JGR Biogeosciences, in press., doi:10.1029/2008JG000913, 2009.

Joabsson, A., Christensen, T. R., and Wallen, B.: Vascular plant controls on methane emissions from northern peat forming wetlands, Trends Ecol. Evol., 14, 385-388, 1999.

Johansson, T., Malmer, N., Crill, P. M., Friborg, T., Åkerman, J. H., Mastepanov, M., and Christensen, T. R.: Decadal vegetation changes in a northern peatland, greenhouse gas fluxes and net radiative forcing, Glob. Change Biol., 12, 1-18, 2006.

Jonsson, A., Karlsson, J., and Jansson, M.: Sources of Carbon Dioxide Supersaturation in Clearwater and $\mathrm{Hu}-$ mic Lakes in Northern Sweden, Ecosystems, 6, 224-235, doi:10.1007/s10021-002-0200-y, 2003.

Jorgenson, M. T., Racine, C. H., Walters, J. C., and Osterkamp, T. E.: Permafrost degradation and ecological changes associated with a warming climate in central Alaska, Climatic Change, 48, 551-579, 2001.

Klinger, L. F., Zimmerman, P. R., Greenberg, J. P., Heidt, L. E., and Guenther, A. B.: Carbon trace gas fluxes along a successional gradient in the Hudson-Bay lowland, J. Geophys. Res-Atmos., 99, 1469-1494, 1994.

Lund, M., Lindroth, A., Christensen, T. R., and Ström, L.: Annual $\mathrm{CO}_{2}$ balance of a temperate bog, Tellus B, 59, 804-811, doi:10.111/j.1600-0889.2007.00303.x, 2007.

Luoto, M., Heikkinen, R. K., and Carter, T. R.: Loss of palsa mires in Europe and biological consequences, Environ. Conserv., 31, 30-37, 2004.

Malmer, N., Johansson, T., and Olsrud, M.: Vegetation, climatic changes and net carbon sequestration in a North-Scandinavian subarctic mire over 30 years, Glob. Change Biol., 11, 18951910, 2005.

McGuire, A. D., Anderson, L., Christensen, T. R., Dallimore, S., Guo, L., Hayes, D., Heimann, M., Lorenson, T., Macdonald, R., and Roulet, N.: Sensitivity of the carbon cycle in the Arctic climate change, Arctic Monitoring and Assessment Porgram (AMAP), 2008.

Nykänen, H., Heikkinen, J. E. P., Pirinen, L., Tiilikainen, K., and Martikainen, P. J.: Annual $\mathrm{CO}_{2}$ exchange and $\mathrm{CH}_{4}$ fluxes on a subarctic palsa mire during climatically different years, Glob. Biogeochem. Cy., 17(1), 1018, doi:10.1029/2002GB001861, 2003.

Oechel, W. C., Vourlitis, G. L., Hastings, S. J., and Bochkarev, S. A.: Change in Arctic $\mathrm{CO}_{2}$ flux over 2 decades - effects of climate-change at Barrow, Alaska, Ecol. Appl., 5, 846-855, 1995.

Oechel, W. C., Vourlitis, G. L., Hastings, S. J., Zulueta, R. C., Hinzman, L., and Kane, D.: Acclimation of ecosystem $\mathrm{CO}_{2}$ exchange in the Alaskan Arctic in response to decadal climate warming, Nature, 406, 978-981, 2000a.

Oechel, W. C., Vourlitis, G. L., Verfaillier Jr., J., Crawford, T., 
Brooks, S., Dumas, E., Hope, A., Stow, D., Boynton, B., Nosov, V., and Zulueta, R.: A scaling approach for quantifying the net $\mathrm{CO}_{2}$ flux of the Kuparuk river basin, Alaska, Glob. Change Biol., 6, 160-173, 2000b.

Rich, J. J. and King, G. M.: Carbon monoxide oxidation by bacteria associated with the roots of freshwater macrophytes, Appl. Environ. Microb., 64, 4939-4943, 1998.

Rinne, J., Riutta, T., Pihlatie, M., Aurela, M., Haapanala, S., Tuovinen, J.-P., and Tuittila, E.-S.: Annual cycle of methane emission from a boreal fen measured by the eddy covariance technique, Tellus B, 59, 449-457, 2007.

Rosswall, T., Flower-Ellis, J. G. K., Johansson, L. G., Jonsson, S., Rydén, B. E., and Sonesson, M.: Structure and function of tundra ecosystems, Stordalen (Abisko), Sweden, Ecol. Bull., 20, 265294, 1975.

Roulet, N. T., Lafleur, P. M., Richard, P. J., Moore, T., Humphreys, E. R., and Bubier, J.: Contemporary carbon balance and late Holocene carbon accumulation in a northern peatland, Glob. Change Biol., 13, 397-411, doi:10.1111/j.13652486.2006.01292.x, 2007.

Rydén, B. E. and Kostov, L.: Thawing and freezing in tundra soils, Ecol. Bull., 30, 251-281, 1980.

Sitch, S., McGuire, A. D., Kimball, J., Gedney, N., Gamon, J., Engstrom, R., Wolf, A., Zhuang, Q., Clein, J., and McDonald, K.: Assessing the carbon balance of circumpolar arctic tundra using remote sensing and process modeling, Ecol. Appl., 17, 213-234, 2007.

Strom, L. and Christensen, T. R.: Below ground carbon turnover and greenhouse gas exchanges in a sub-arctic wetland, Soil Biol. Biochem., 39, 1689-1698, 2007.

Svensson, S.: Snow cover dynamics and plant phenology documentation using digital camera images and their relation with $\mathrm{CO} 2-$ fluxes at Stordalen mire, Northern Sweden, MSc, Geobiosphere Science Centre, Physical Geography and Ecosystems Analysis, Lund University, Lund, 2004.
Tiiva, P., Rinnan, R., Faubert, P., Rasanen, J., Holopainen, T., Kyro, E., and Holopainen, J. K.: Isoprene emission from a subarctic peatland under enhanced UV-B radiation, New Phytol., 176, 346-355, 2007.

Tiiva, P., Faubert, P., Michelsen, A., Holopainen, T., Holopainen, J. K., and Rinnan, R.: Climatic warming increases isoprene emission from a subarctic heath, New Phytol., 180, 853-863, doi:10.1111/j.1469-8137.2008.02587.x, 2008.

Treat, C. C., Bubier, J. L., Varner, R. K., and Crill, P. M.: Timescale dependence of environmental and plant-mediated controls on $\mathrm{CH}_{4}$ flux in a temperate fen, J. Geophys. Res-Biogeosci., 112, G01014, doi:10.1029/2006JG000210, 2007.

Turetsky, M. R., Wieder, R. K., and Vitt, D. H.: Boreal peatland $\mathrm{C}$ fluxes under varying permafrost regimes, Soil Biol. Biochem., 34, 907-912, 2002.

van Dongen, B. E., Semiletov, I., Weijers, J. W. H., and Gustafsson, Ö.: Contrasting lipid biomarker composition of terrestrial organic matter exported from across the Eurasian Arctic by the five great Russian Arctic rivers, Glob. Biogeochem. Cy., 22, GB1011, doi:10.1029/2007GB002974, 2008.

Walter, K. M., Zimov, S. A., Chanton, J. P., Verbyla, D., and Chapin, F. S.: Methane bubbling from Siberian thaw lakes as a positive feedback to climate warming, Nature, 443, 71-75, 2006.

Walter, K. M., Smith, L. C., and Chapin III, F. S.: Methane bubbling from northern lakes: present and future contributions to the global methane budget, Philos. T. R. Soc. A., 365, 1657-1676, doi:10.1098/rsta.2007.2036, 2007.

Wille, C., Kutzbach, L., Sachs, T., Wagner, D., and Pfeiffer, E.-M.: Methane emission from Siberian arctic polygonal tundra: eddy covariance measurements and modeling, Glob. Change Biol., 14, 1395-1408, doi:10.1111/j.1365-2486.2008.01586.x, 2008.

Zimov, S. A., Schuur, E. A. G., and Chapin, F. S.: Permafrost and the global carbon budget, Science, 312, 1612-1613, 2006.

Zuidhoff, F. S. and Kolstrup, E.: Changes in palsa distribution in relation to climate change in Laivadalen, Northern Sweden, especially 1960-1997, Permafrost Periglac, 11, 55-69, 2000. 